\title{
Criteria to evaluate effectiveness of creating consolidated group of taxpayers
}

\author{
Alena Khaperskaya ${ }^{1, \mathrm{a}}$, Kristina Bannova ${ }^{1}$, and Natalia Pokrovskaia ${ }^{2}$ \\ ${ }^{1}$ Tomsk Polytechnic University, 634050 Lenin Avenue, 30, Tomsk, Russia \\ ${ }^{2}$ Saint Petersburg State University, 199034 Universitetskaya nab., 7/9, Saint Petersburg, Russia
}

\begin{abstract}
Fiscal relations and the mechanisms of their functioning are the subject of studies by foreign and domestic economists, as the taxation relations are what enables the state regulation of the economy. In 2012 the legislative act "On consolidated groups of taxpayers" (CGTs) was adopted, setting the norms and rules governing the relations between the tax authority and the taxpayers that are the participants of CGTs. In this regard, CGTs are one of the most important factors in the socio-economic development of the society. One of the main goals while introducing CGTs was improving the economic justifiability of the distribution of profit tax proceeds among the territories of the Russian Federation. In 2012-2014 the possibility of achieving the above-mentioned goal through the introduction of CGTs was evaluated, based on the analysis of the tax base and the profit tax by the respective authority's jurisdiction, the type of business activities and the consolidated groups of taxpayers.
\end{abstract}

\section{Introduction}

Modern tax system is not static. It is constantly changing and improving. The modern development of the economy and economic actors has an impact on the transformation of the tax system, both for individual taxes and developing new tax regimes for specific groups of economic entities. A holding structure often is the major employer not only for individual small towns and cities, but for entire regions.

In this regard they actively influence the interbudgetary relations and redistributions of financial and tax streams. In recent years the special system of the taxation affecting actively the redistribution of tax streams in holding structures by means of creation of the voluntary consolidated groups of taxpayers (CGT) has been developing.

The complexity of the consideration of such institution as consolidated groups of taxpayers lies in the absence of CGT, as in the Russian and foreign experience there is no one specific theoretical concept of the creation of CGT. Similar associations in Germany have received the name of associated enterprises «Organschaft» [2].

In France, similarly to other countries, the Institute of consolidation is subject to the EU Directive "parentsubsidiaries". The Swedish system of «liberation» implies the exemption from taxation of income from capital gains and dividends on shares owned for purposes of business activity.
The main feature of the enterprises belonging to such associations was a complicated organizational legal form, a huge staff of employees. These associations were characteristic of a large part of major companies of Western Europe and the U.S. with a holding structure and as a result they are saddled with paperwork. The examples of such companies are General Electric (USA), Chevron (USA), Petrochina (China), Toyota Motor (Japan) Roche HLDG (Switzerland) and others.

The institute of voluntary consolidation of tax obligations for groups in the Russian Federation has been introduced for the largest taxpayers since January 1, 2012 [1]. The Russian restrictions for recognition of taxpayers activity enough for formation the CGT are high in comparison with the criteria established in the developed countries. As a result of the high criteria established in the Russian legislation for formation of CGT in 2013 only 1559 companies $(0,15 \%$ of all taxpayers paying corporate profit tax) could create 15 groups of the consolidated taxpayers.

\section{Russian model of group taxation and its effectiveness}

In 2010, the Russian Ministry of Finance published draft of the Federal law "On amendments to part one and part two of the Tax code of the Russian Federation in connection with the establishment of the consolidated group of taxpayers". Anticipated term of entry into force

\footnotetext{
a Corresponding author: khape@mail.ru
} 
of this amendment, simultaneously with the entry into force of the new rules in transfer pricing, was 1 January 2012. Compared with the previous rules the new version of the criteria values for the establishment of the CGT underwent changes [10]. It should be noted that during the two years of discussing the Federal laws concept most of its provisions remained unchanged. In particular, the application of a consolidated group of taxpayers is possible only by Russian organizations that do not have separate subdivisions outside Russia and only in respect of corporate profit tax.

Modifications to the criteria may be associated with the range entry in the consolidated group of taxpayers, since many legislators had requested reducing the barrier to entry in the consolidated group of taxpayers for inclusion in the Institute of the consolidated taxpayer more companies. Unfortunately, the Federal law is oriented only to a narrow group of large taxpayers, so few companies will be able to benefit from the CGT regime.

Objectives for introduction of CGT in Russia were regional budgets problems because of unexpected corporate profit tax base distribution among the territories of Russia by largest companies such as: transfer pricing transactions between companies belonging to the group and not controlled by the tax authorities; the problem of dividing the business into smaller in order to move to the special regime.

At the moment, analyzing the effectiveness of a consolidated groups of taxpayers modern authors consider only the existing system, without paying sufficient attention to the criteria of the formation of the CGT and prospects of their change.

We can distinguish two groups of works: the first focused on statistical models CGT creation (analysis of the dynamics of economic performance of the companies after they entered the consolidated group of taxpayers); the second contains proposals to change requirements of joining the consolidated groups of taxpayers in the absence of a unified theoretical approach to the model tax CGT

The Russian mechanism of CGT needs a revision in the following areas:

- the conditions of membership in consolidated group of taxpayers;

- the requirements for the creation of CTG, which must be complied with throughout the period of the group's action, as well as requirements to be met only while the creation of CTG;

- the procedure for amending the treaty establishing the consolidated group of taxpayers in the case of the reorganization of its members;

- changing of the responsible party in consolidated group of taxpayers, transfer of authority from the former responsible member in consolidated group of taxpayers to the new one, in particular, submission of tax returns for the corporate profit tax, tax payment (advance payment) and collection of tax carrying out audits and prosecution for tax violations;

- the procedure for corporate profit tax apportionment among the regional budgets in the
Russian Federation on the location of the CGT participants and their subdivisions;

- order the consolidated groups of taxpayers' responsible party to offset corporate profit tax paid by members of the consolidated group outside of the Russian Federation;

- the use by the CGT participants of tax rate established in Russia for certain categories of taxpayers with simultaneous analysis of changes in the tax base for corporate profit tax, which will consider the impact of reduced rates of tax.

\section{Fiscal efficiency of CGT}

The operation of the CGT supports the migration of corporate profit tax base between regions, in particular, in 2012 in 23 subjects of the Russian Federation (28\% of the total number of regions) there was a reduction of corporate profit tax in the amount of 44.6 billion rubles, and in 60 subjects of the Russian Federation (72\% of the total number of regions) increased receipts of corporate profit tax in the amount of 29.1 billion rubles, in connection with the formation of consolidated groups [11-12]. Redistribution of corporate profit tax proceeds as a result of creating consolidated groups of taxpayers in 2014 is presented in table 1 .

Table 1. Changing in corporate profit tax proceeds to regional budgets as a result of creating consolidated groups of taxpayers in 2014

\begin{tabular}{|c|c|c|c|c|}
\hline \multirow{2}{*}{$\begin{array}{l}\text { The range } \\
\text { of } \\
\text { changing } \\
\text { in } \%\end{array}$} & \multicolumn{2}{|l|}{ Increase } & \multicolumn{2}{|c|}{ Decrease } \\
\hline & $\begin{array}{l}\text { Number } \\
\text { of } \\
\text { regions }\end{array}$ & $\begin{array}{l}\text { CPT } \\
\text { proceeds, } \\
\text { billion } \\
\text { rubles }\end{array}$ & $\begin{array}{l}\text { Number } \\
\text { of } \\
\text { regions }\end{array}$ & $\begin{array}{l}\text { CPT } \\
\text { proceeds, } \\
\text { billion } \\
\text { rubles }\end{array}$ \\
\hline $\begin{array}{l}\text { from } 0 \text { to } \\
1\end{array}$ & 11 & 0,3 & 9 & $-0,4$ \\
\hline $\begin{array}{l}\text { from } 1 \text { to } \\
3\end{array}$ & 12 & 2,7 & 6 & $-2,4$ \\
\hline $\begin{array}{l}\text { from } 3 \text { to } \\
10\end{array}$ & 17 & 7,9 & 8 & $-55,9$ \\
\hline $\begin{array}{l}\text { from } 10 \text { to } \\
30\end{array}$ & 6 & 10,2 & 8 & $-63,5$ \\
\hline $\begin{array}{l}\text { more than } \\
30\end{array}$ & 7 & 40,8 & 1 & $-4,8$ \\
\hline total & 53 & 61,9 & 32 & $-127,0$ \\
\hline
\end{tabular}

Source [9]

In 2014, was imposed a moratorium on the formation of new consolidated groups. The proposed three-year moratorium is not justified. It was the time for analyzing the data and, if necessary, for preparation of proposals on improvement the legislation within one or two years. This moratorium worsens the position of those taxpayers who only planned to create a consolidated group and has held this preparatory work. 
The most affected by the extension of the moratorium, according to RUIE (Russian Union of Industrialists and Entrepreneurs), will be the companies that in 2014 were registered in the tax office the treaties establishing the consolidated group of taxpayers. The moratorium provided that such fully executed agreements are effective from 1 January 2016.

"Now, in violation of all obligations made by the state about their entry into force will be delayed for another 3 years", - said RUIE.

"There is a new potential limitation is that the consolidated group of taxpayers must be created for a period of not less than 5 years, the newly included into the group of participants cannot be excluded from it earlier than 5 years after inclusion, and excluded participants could not be included back into the group earlier than 5 years after exclusion. This idea was not discussed and it is difficult to support in full", - stated in the message.

From the point of view of increasing predictability of revenues of regional budgets, five-year term in any case is redundant. As noted by the Russian Union of Industrialists and Entrepreneurs, the real "depth" of budget planning in the regions and at the Federal level is 3 years.

After wide discussion the government to extend the moratorium on the formation of new consolidated groups of taxpayers until 2018.

Payment of corporate profit tax through the responsible member of the CGT led to a redistribution of the tax base between regions, and some regions suffered from this. However, as noted the Minister of Finance Anton Siluanov at the parliamentary hearings on the main directions of tax policy for the years 2016-2018, after the introduction of CGT in 201453 regions had increased tax base, and 32 regions had decreasing in corporate profit tax revenue. Generally decrease in tax proceeds happened at such large regions as Moscow and Khanty-Mansiysk Autonomous district that didn't lead to formation of deficiency of the regional budget in general.

\section{Additional criteria to evaluate effectiveness of CGT}

A particular challenge at the moment is the issue of developing criteria to assess and predict the effectiveness of established and proposed for the establishment consolidated groups of taxpayers. As we discuss before, an efficiency of the created CGT is often evaluated only by one criterion - fiscal efficiency. The answer to the question: is a CGT efficient or not? - is often in the sphere of tax proceeds level regarding regional and federal budgets of the Russian Federation. In our opinion fiscal efficiency could not be only criterion in evaluation of CGT.

All criteria of effectiveness of the CGT can be divided into three large groups:

1. Investment;

2. Economic;

3. Social [7].
Among investment criteria need to be considered the issues of flexibility in construction of consolidated groups of taxpayers.

Flexibility means ability to react adequately to change of a macroeconomic situation in the country and to change in phases of a business cycle, and also to correct investment streams, choosing priority and attractive branches of economy. Example of a flexible tax for example, is the corporate profit tax, smoothing the business cycle and acting as automatic stabilizers. This tax in the phase of recovery could hinder entrepreneurial activity, because the increase of tax burden is faster than profit growth. And, conversely, the burden of tax at the stage of decline is shrinking faster than profits, encouraging entrepreneurs to increase activity.

For an assessment of economic criteria, in our opinion, it is necessary to define harmony of tax burden, to minimize administrative expenses, an assessment of the discouraging effects of change in the interbudgetary streams, and also to estimate a branch orientation of real and planed CGT, for the purpose of introduction additional coefficients, for redistribution of the interbudgetary streams.

Social criteria includes the actual (projected) favorable social implications of CGT. Among them:

a) the promotion of the wellbeing categories of taxpayers;

b) improvement of the availability and quality of services to the population of the region in the field of education, culture, art, physical culture and sport, healthcare and social security;

b) creation of favourable conditions for activity that use the labour of people who need government support [8].

The interrelation and the contradiction of criteria allow assessing the advantages and the drawbacks of the existing tax regime. For example, tax incentives are fair, but they distort the tax system, which leads to economic inefficiency.

On the basis of the identified criteria it is necessary to develop a methodology for evaluating the effectiveness of the CGT, for assessment a system of interaction among participants of consolidated groups of taxpayers and the state.

Because at association in CGT we deal with the major companies, process of entry into CGT demands certain time. Economic instability could change the tax base for corporate profit tax and their distribution. As a result the process of regional budgets adaptation in redistribution of tax proceeds, is associated with the CGT.

\section{Conclusion}

The objective of the methodology should be identified within the designated criteria - sub-criteria affecting the efficiency of creation and functioning of a consolidated group of taxpayers; detection of correlation between investment, economic and social factors in interaction between CGT and the external environment; 
development of recommendations for optimization of entry threshold to CGT.

The information base may make extracts from the register, different certificates issued by members of the consolidated group of taxpayers, copies of payment orders for payment of VAT, excises, corporate profit tax and the mineral extraction tax (copies of tax authority decisions on the offsetting according to taxes), balance sheets, profit and loss statement for the preceding calendar year for each member of the group and other normative-legal acts on accounting.

Correct and complete evaluation of effectiveness in creation and functioning of consolidated groups of taxpayers will form the applicable tax legislation in the Russian Federation on the CGT changes and adjustments that are conducive to attract additional financial resources to the consolidated budget of the Russian Federation, which in turn will allow them to finance the investment activities associated with the development of technology and research funding, to engage new areas and new activities in economic sphere

\section{Acknowledgment}

The study was financially supported by the Russian Foundation for Humanities (RFH) in the frame of the project for scientific studies (Modelling the conditions of the tax liabilities consolidation to mitigate the conflict of interest among the state and taxpayers), project No. 1532-01341.

\section{References}

1. K.A. Bannova, I.N. Dolgih, A.B. Zhdanova, N.V. Pokrovskaya, Innovation Management and Sustainable Economic Competitive Advantage: From Regional Development to Global Growth The 26th IBIMA conference in Madrid. (2015)

2. N.E. Aktaev, K.A. Bannova, A.S. Balandina, I.N. Dolgih, N.V. Pokrovskaia, U.A. Rumina, A.B. Zhdanova, K.N. Akhmadeev, Procedia - Social and Behavioral Sciences, 166 (2015)

3. A. V. Khaperskaya, K. A. Bannova, S. Z Musina, International Conference on Economics and Management (ICEM) (2015)

4. A. Pogorletskiy and Söllner, F., Intereconomics, 43 (5), 288-297 (2008)

5. I. Mayburov, Y. Leontyeva, Transport tax in Russia as a promising tool for the reduction of airborne emissions and the development of the road network WIT Transactions on Ecology and the Environment (2015)

6. V. Ivanov, V. Mishchenko and O. Maliutin, Actual Problems of Economics, 166 (2015)

7. JONATHAN R. KESSELMAN 7 - Income-Tested Transfer Programs (1982)

8. GCPL consolidated net up $2 \%$ on higher tax, operating expenditure, Focus on Surfactants, 12, 7 (2013)

9. Carmen Comaniciu, Liliana Bunescu, Procedia Economics and Finance, 6, 615-620 (2013)
10. Aziz Jaafar', John Thornton, The International Journal of Accounting, 50 (4), 435-457 (2015) Don Herrmann, Tatsuo Inoue, Wayne B Thomas, Advances in International Accounting, 16, (2003)

11. Prof Qingyue Meng, PhD, Prof Hai Fang, $\mathrm{PhD}^{\mathrm{a}}$, Xiaoyun Liu, $\mathrm{PhD}^{\mathrm{a}}$, Beibei Yuan, $\mathrm{PhD}^{\mathrm{a}}$, Jin $\mathrm{Xu}, \mathrm{BA}^{\mathrm{a}}$ THE LANCET, 386, 10002 (2015)

12. I.S. Antonova, O.A. Negodina, D.D. Vavilov, 26th International Business Information Management Association Conference: Proceedings, Madrid: $\operatorname{IBIMA}(2015)$ 